\title{
Multiple Sclerosis: A Mast Cell Mediated Psycho-Somatic Disease?
}

\author{
Per Gøran Krüger \\ University of Bergen, Bergen, Norway \\ Email: per.kruger@biomed.uib.no
}

How to cite this paper: Krüger, P.G. (2018) Multiple Sclerosis: A Mast Cell Mediated Psycho-Somatic Disease? World Journal of Neuroscience, 8, 444-453. https://doi.org/10.4236/wjns.2018.84035

Received: September 25, 2018

Accepted: November 3, 2018

Published: November 6, 2018

Copyright $\odot 2018$ by author and Scientific Research Publishing Inc. This work is licensed under the Creative Commons Attribution International License (CC BY 4.0).

http://creativecommons.org/licenses/by/4.0/

\begin{abstract}
This paper reviews evidence that the presence of mast cells in specific sites of central nervous system, suggesting inflammatory processes, may explain all the symptoms observed in multiple sclerosis. This hypothesis would be relatively easy to test.
\end{abstract}

\section{Keywords}

Multiple Sclerosis, Mast Cells, Blood-Brain Barrier, Oedemas, Plaque Formation, Relapsing-Remitting MS, Primary and Secondary

Progressive MS, Nutrition, Stress, Enteroendocrine System

\section{Introduction}

It has been widely accepted that multiple sclerosis (MS) is an autoimmune, genetic disease. This statement has been included in the introduction to nearly every scientific report on MS, even though so many reports were published that exclude the genetic factor.

MS has an uneven geographical distribution and a changing incidence over time in several areas of the world. In Norway, the rate of the disease is lower in the far north of the country than it is in the South West. MS was earlier a typical inland disease; however the latest 50 - 70 years has become just as common at the coast as in the inlands [1] [2] [3] [4] [5]. MS does nearly not exist in Africa, Indian subcontinent, and the West Indies, yet children of immigrants from these areas born in UK show the same high prevalence of MS as the endogeneous population [6]. Migration studies indicate that some parts of the disposition for MS are already acquired by the age 15 in high-risk areas, and therefore that MS is also an environmental disease ordinary acquired in adolescence with an incubation period before symptom onset [7]. This suggests that some exogenous 
factor(s) are involved such as latitude [8] or nutritional habits. The prevalence of MS is high in all parts of northern Europe and in the USA [9] [10] [11], and the highest rates are observed from the Orkney Islands in the UK.

It has been observed that concordance rates among monocygotic twin pairs are constantly higher than among dizygotic pairs [12] [13] [14]. It seems, however, that the concordance rates even for dizygotics are higher than that it would be expected from sibship risk [15]. The observations on twins seem to indicate that in the first years of life, the environmental exposure for dizygotic twins is likely to be more similar than for brothers and sisters that are not twins, and this is probably even more so for monocygotic twins. The raised concordance rate in dizygotic twins is compatible with the hypothesis that events at early part of life are important in determining the subsequent risk of MS [16]. From all these facts we conclude that multiple sclerosis is unlikely to be a genetic disease.

\section{There Are Five Facts Characterizing MS}

1) Nuclear magnetic resonance imaging of MS-patients brains revealed a dynamic process locally in white matter due to repeated blood-brain barrier damage with subsequent oedema formations [17].

2) The development of areas in white matter in which myelin has dissolved: plaque(s) formation. In autopsies these are easily observed (Figure 1).

3) The autopsies normally reveal accumulation of lymphocytes (T-lymphocytes) [18] around venules (as demonstrated in Figure 2 and Figure 3).

4) Clusters of mast cells along the venules, mostly at borderzones of the MS-plaques, see e.g. Figure 4 and Figure 5 [19]-[26]. The mast cell has surface IgE-receptors and is the connective tissue cell equivalent to the blood basophil.

5) Elevated mast cell protease (tryptase) in cerebrospinal fluid of MS-patients. [27].

In normal unaffected human brain mast cells are present only in a few restricted places: area postrema, infundibulum, in the pineal organ (and its surrounding leptomeninges) as well as in the choroid plexus, but not elsewhere in

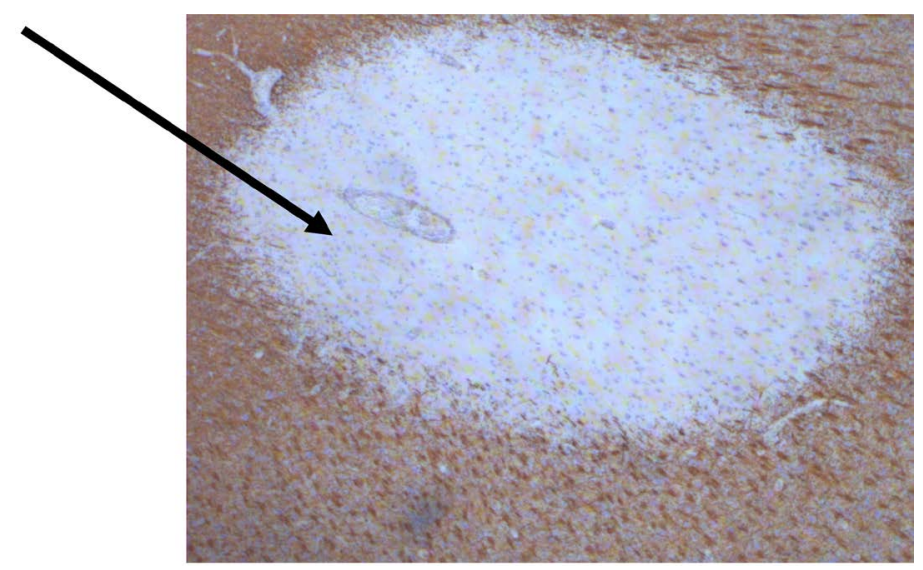

Figure 1. MS-Plaque in CNS white matter (arrow), surrounded by intact white matter (Stained for myelin basic protein) $(40 \times)$. 


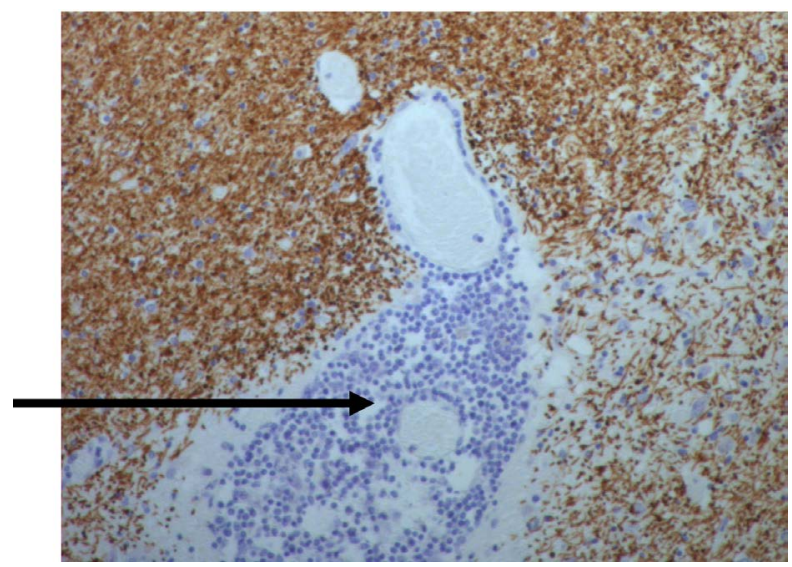

Figure 2. Lymphocytes (arrow) accumulated at venule (Stained for myelin basic protein) $(100 \times)$.

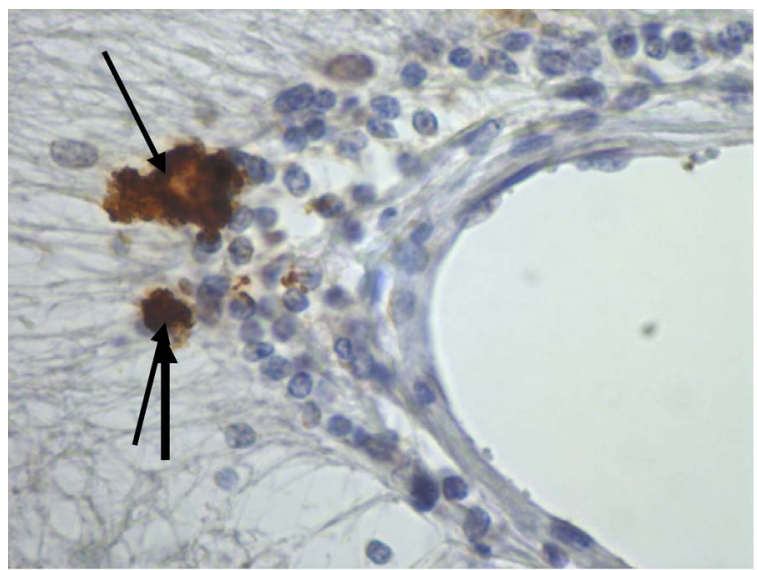

Figure 3. lymphocytes at venule (Stained for mast cell tryptase (arrows: mast cells) $(400 \times)$.

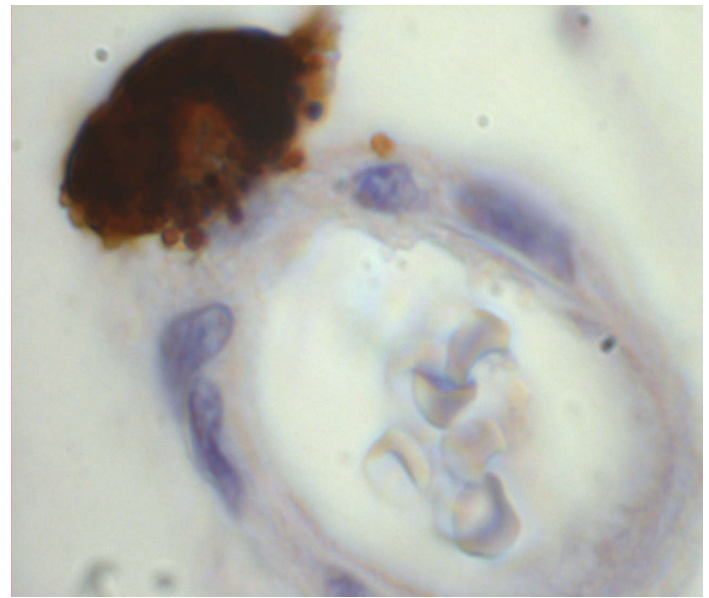

Figure 4. Mast cell at venule in plaque borderzone. Stained for mast cell Tryptase $(1600 \times)$.

the brain and spinal chord [28]. In MS-brain autopsies mast cells were originally observed by Neumann in 1890 [19] and confirmed by others to be in close contact 


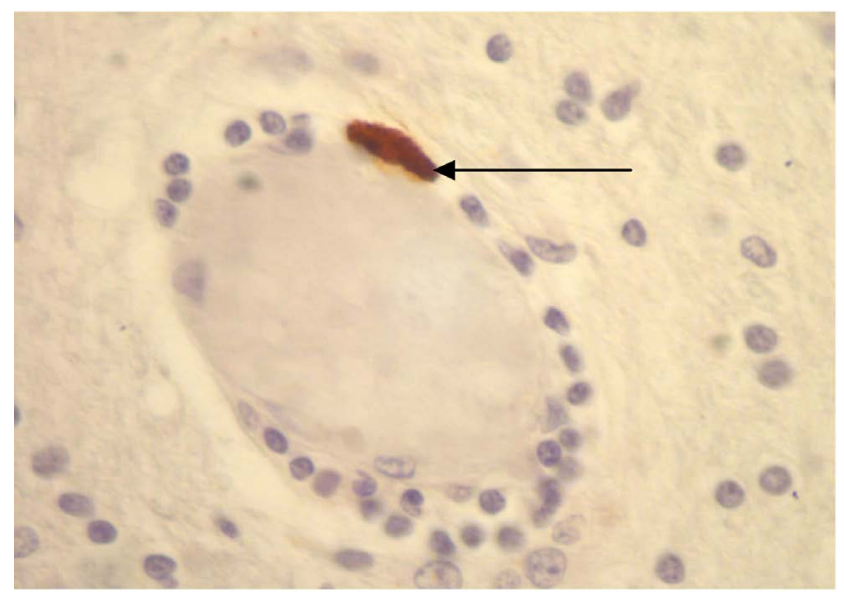

Figure 5. Mast cell at borderzone of MS-plaque (arrow). Stained for mast cell chymase $(400 \times)$.

to MS-plaques. Most scientists focusing on MS conclude that the numbers of ectopic places of mast cells is too small to be of significance. However, reconstruction and applying more relevant staining-techniques have revealed that the numbers of mast cells are ten times higher than hitherto observed. They are clustered along venules in the plaque borderzones [25] as demonstated in e.g. Figure 6 and Figure 7. In addition, the numbers of mast cells in females are twice as high as in males [26] which coincide with higher level of MS in women than in males [29]. Moreover, it is known that mast cell proteases may dissolve the protein of the myelin sheaths [30], thus may be the reason for the observed demyelinization (plaque formation) in MS. Further on: Mast cells survive stimulation and massive release of all their mediators, as e.g. histamine and proteases, and in weeks or months may be completely reloaded [31] [32]. This may explain the relapsing-remitting phases of MS. The massive release of histamine and proteases probably leads to oedema formations and demyelinization character-rized by the relapsing phase. In contrast the remitting phase occurs when the mast cells reload the mediator stores. Primary and secondary progressive MS may be the result of graded and/or continuous stimulation of the slowly increasing mast cell population starting from various basepoints. From these observations it seems relevant to forward the question if mast cells are the key to MS [33].

I suggest that the mast cell population recruited to CNS early in life of the $M S$-patient-to-be is functional and phenotypical different from mast cells of the rest of the body, as a result of a childhood infection. We know that mast cells can develop into phenotypically, and functionally, distinct subpopulations. Evidence indicates that some of these subpopulations can manifest substantial plasticity and permit mast cells to respond to various ligands [34]. This implies that mast cells can modify to cytokine signals, epigenetic modifications and other microenvironmental factors.

Mast cells are recruited from bone marrow as the functionally close "relative" 


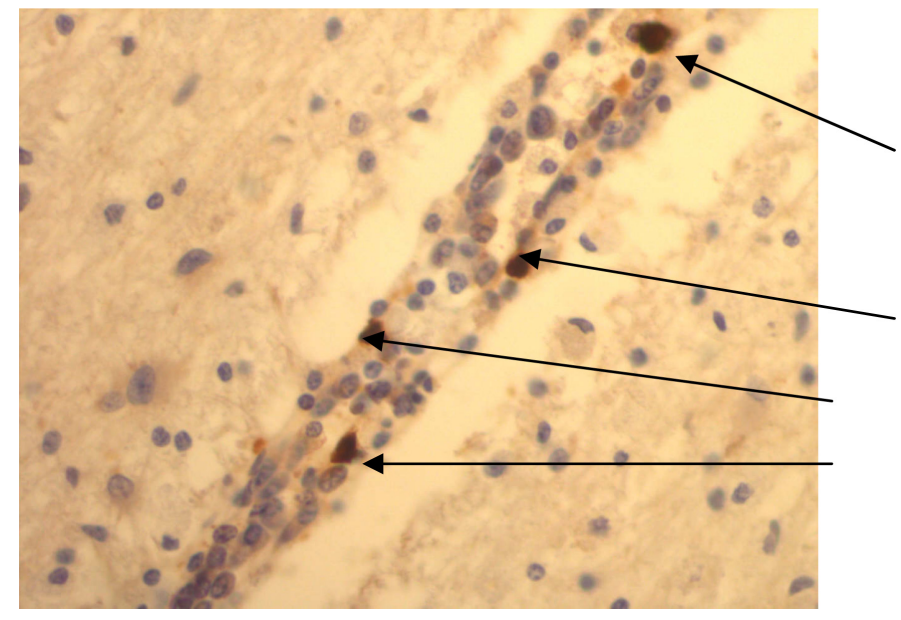

Figure 6. Mast cells along a venule in plaque borderzone (arrows). Stained for mast cell tryptase $(250 \times)$.

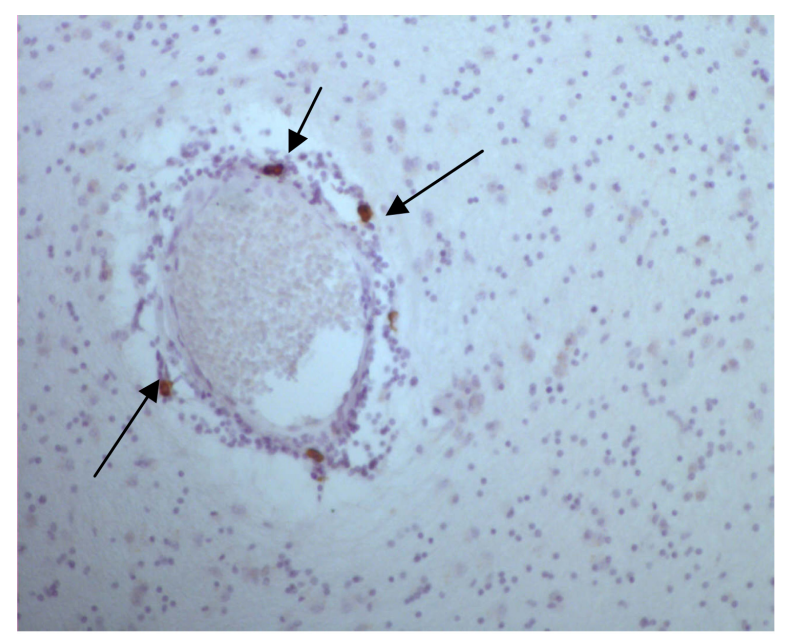

Figure 7. Mast cells at venule in borderzone of MS-plaque (arrows). Stained for mast cell chymase $(100 \times)$.

to blood basophils, although the exact lineage is not elucidated. It has been suggested that the mast cell may be a derivative of the monocyte [35]. Resent observations support this theory; Mast cells may be provoked to express HMC-2 receptor [36], and may be active phagocytic [37]. Mast cells may be recruited not only from invading mast cells, but even from monocytes and transformed to mast cell phenotype of the MS-brain.

The mast cell produces a long range of mediators stored in secretory granules that are released upon stimulation of the cells, e.g. histamine, heparin and proteases. This is a relatively quick process with a time range of seconds to minutes summarized in e.g. [38]. A delayed secretory process is normally initiated that may take many minutes to hours where also a long range of mediators are produced and released, among them Il-1 which is a potent chemoattractant for T-lymphocytes, and thus may explain the observed accumulation of $\mathrm{Tl}$ at venules of the MS-plaques [18]. 
The actual stimulations of mast cells may be many-fold, and of course the most well-known is the allergic reaction in which the inborn IgE-receptors on mast cell surface are stimulated by the appropriate antigen. However, a long range of stimulatory substances and situations have been described, of which some seems to be relevant for MS as various stress situations (mental and physical) that has been reported as important factors for the stimulation of mast cells [39] [40]. This is relevant in the present context since mast cells may regulate blood-brain barrier [39], and that stress is a risk factor for multiple sclerosis [41] [42] Catestatin, (fragment of chromogranin-A, which is coreleased with hormones from the enteroendocrine system) is a potent releasing factor for mast cells [43] and may obviously be a part of stress-related stimulatory factors for mast cells.

In this context even nutritional factors may be stress-factors for the entero-endocrine system [44].

\section{Perspectives}

From migration studies it is obvious that disposition for multiple sclerosis is established early in life (before the teens) and is not a genetic disease. They also point to environmental or behavioural factors. Whether the massive presence of mast cells is the direct releasing factor for the induction and maintenance of MS, or just a secondary response to immune-reactions going on, may be hard to confirm. However, their presence may in itself explain all symptoms we observe in the start and maintenance of MS, from the early observations of oedemas, myelin-destruction, plaque formation and the remitting-relapsing phases so often observed.

As for the eventually mast cell releasing factors it seems that the observations of latitude/environmental influence on development of MS is probably both nutritional and behavioural. The incidence of MS within the last 50 - 70 years changed from being a typical inland disease in Norway to also being more common at the coast. The nutritional habits in Norway have probably changed dramatically at the coast from being dependent on fat fish (herring etc.) and simple vegetables to "inland" habits (meat and "junk-food"?). The high incidence of MS at the Orkney islands seems to contradict [9] and has been evaluated as a genetic disposition: a result of the establishment of American troups during the last world war. At these islands mutton and whale has for long been important parts of the nutrition habits, and since last war probably also American canned food. This aspect does not seem to have been evaluated.

Our enteroendocrine system is highly sensitive to nutritional factors [44], as well as for mental stress, and may even be the basis for ultimate releasing factors for mast cells in the brain. The disposition being invasion of mast cells as a consequence of childhood infection, e.g. measles, since disposition for MS is established before the teens.

Whether or not mast cells play an important role in the symptoms of multiple 
sclerosis could be tested by blocking mast cells' actions in the human brain, and/or by limiting the effects of released histamine. Today's drugs with such actions on mast cells carry too much side effects to be ethic to use. A challenge for the pharmaceutical industry would be to invent mast cell blocker and antihistamines with as little side effects as possible.

\section{Conflicts of Interest}

The author declares no conflicts of interest regarding the publication of this paper.

\section{References}

[1] Midgard, R., Riise, T. and Nyland, H. (1991) Epidemiologic Trends in Multiple Sclerosis in Møre and Romsdal, Norway: A Prevalence/Incidence Study in a Stable Population. Neurology, 41, 887-892. https://doi.org/10.1212/WNL.41.6.887

[2] Grønning, M., Riise, T., Kvale, G., Nyland, H., Larsen, J.L. and Aarli, J.A. (1991) Incidence of Multiple Sclerosis in Hordaland, Western Norway: A Fluctuating Pattern. Neuroepidemiology, 10, 53-61. https://doi.org/10.1159/000110247

[3] Larsen, J.L., Aarli, J.A., Nyland, H. and Riise, T. (1984) Western Norway, a High-Risk Area for Multiple Sclerosis: A Prevalence/Incidence Study in the County of Hordaland. Neurology, 34, 1202-1207. https://doi.org/10.1212/WNL.34.9.1202

[4] Grønning, M. and Mellgren, S.I. (1985) Multiple Sclerosis in the Two Most Northern Counties of Norway. Acta Neurologica Scandinavica, 72, 321-327. https://doi.org/10.1111/j.1600-0404.1985.tb00878.x

[5] Grytten, N., Glad, S.B., Aarseth, J.H., Nyland, H., Midgard, R. and Myhr, K.-M. (2006) A 50-Year Follow-Up of the Incidence of Multiple Sclerosis in Hordaland County, Norway. Neurology, 66, 182-186. https://doi.org/10.1212/01.wnl.0000195549.95448.b9

[6] Elian, M., Nightingale, S. and Dean, G. (1990) Multiple Sclerosis among United Kingdom-Born Children of Immigrants from Indian Subcontinent, Africa and the West Indies. Journal of Neurology, Neurosurgery \& Psychiatry, 53, 906-911. https://doi.org/10.1136/jnnp.53.10.906

[7] Kurtzke, J.F. (1991) Multiple Sclerosis: Changing Times. Neuroepidemiology, 10, 1-8. https://doi.org/10.1159/000110240

[8] Granieri, E., Casetta, I. and Tola, M.R. (1995) Epidemiology of Multiple Sclerosis in Italy and Southern Europe. Acta Neurologica Scandinavica, S161, 60-70. https://doi.org/10.1111/j.1600-0404.1995.tb05859.x

[9] Poskanzer, D.C., Prenney, L.B., Sheridan, J.L. and Kondy, J.Y. (1980) Multiple Sclerosis in the Orkney and Shetland Islands. 1. Epidemiology, Clinical Factors, and Methodology. Journal of Epidemiology and Community Health, 34, 229-239. https://doi.org/10.1136/jech.34.4.229

[10] Lauer, K. and Firnaber, W. (1992) Epidemiologic Aspects of Multiple Sclerosis. Versicherungsmedizin, 44, 125-130.

[11] Ebers, G.C. and Sadovnick, A.D. (1993) The Geographic Distribution of Multiple Sclerosis: A Review. Neuroepidemiology, 12, 1-5. https://doi.org/10.1159/000110293

[12] Bobowick, A.R., Kurtzke, J.F., Brody, J.A., Hrubec, Z. and Gillespie, M. (1978) Twin study of Multiple Sclerosis: An Epidemiologic Inquiry. Neurology, 28, 878-987. 
https://doi.org/10.1212/WNL.28.10.978

[13] Kinnunen, E., Koskenvus, M., Vario, J. and Ano, K. (1987) Multiple Sclerosis in a Nationwide Series of Twins. Neurology, 37, 1627-1629. https://doi.org/10.1212/WNL.37.10.1627

[14] Heltberg, A. (1987) Twin Studies in Multiple Sclerosis. The Italian Journal of Neurological Sciences, Suppl. 6, 35-39.

[15] James, W.H. (1985) Sib Risk and the Dizygotic Twin Concordance Rate for Multiple Sclerosis. Journal of Epidemiology \& Community Health, 39, 39-43. https://doi.org/10.1136/jech.39.1.39

[16] Matthews, W.B. (1991) McAlpine's Multiple Sclerosis. 2nd Edition, Edinburgh Churchill Livingstone.

[17] Kermode, A.G., Tofts, P.S., Thompson, A.J., et al. (1990) Heterogeneity of Blood-Brain Barrier Changes in Multiple Sclerosis: An MRI Study. Neurology, 40, 229-235.

https://doi.org/10.1212/WNL.40.2.229

[18] Fletcher, J.M., Lalor, S.J., Sweeney, C.M., Tubridy, N. and Mills, K.H.G. (2010) T Cells in Multiple Sclerosis and Experimental Autoimmune Encephalomyelitis. Clinical \& Experimental Immunology, 162, 1-11. https://doi.org/10.1111/j.1365-2249.2010.04143.x

[19] Neumann, J. (1890) Über das Vorkommen der sogenannten "Mastzellen" bei pathologishen Veränderung des Gehirns. Virchows Archiv, 122, 378-380. https://doi.org/10.1007/BF01884453

[20] Olsson, Y. (1974) Mast Cells in Plaques of Multiple Sclerosis. Acta Neurologica Scandinavica, 50, 611-618. https://doi.org/10.1111/j.1600-0404.1974.tb02806.x

[21] Thoms, R., Weiner, H.L. and Johnson, D. (1990) Identification of IgE-Positive Cells and Mast Cells in Frozen Sections of Multiple Sclerosis Brains. Neuroimmunology, 30, 167-177. https://doi.org/10.1016/0165-5728(90)90101-R

[22] Theoharides, T.C. (1990) Mast Cells: The Immune Gate to the Brain. Life Sciences, 46, 607-617. https://doi.org/10.1016/0024-3205(90)90129-F

[23] Krüger, P.G., Bø, L., Myhr, K.-M., Karlsen, Å.E., Taule, A., Nyland, H. and Mørk, S. (1990) Mast Cells and Multiple Sclerosis: A Light and Electro Microscopic Study of Mast Cells in Multiple Sclerosis Emphasizing Staining Procedures. Acta Neurologica Scandinavica, 81, 31-36. https://doi.org/10.1111/j.1600-0404.1990.tb00927.x

[24] Ibrahim, M.Z.M., Reder, A.T., Lawand, R., Taksh, W. and Sallouh-Khatib, S. (1996) The Mast Cells of the Multiple Sclerosis Brain. Journal of Neuroimmunology, 70, 131-138. https://doi.org/10.1016/S0165-5728(96)00102-6

[25] Krüger, P.G. (2001) Mast Cells and Multiple Sclerosis: A Quantitative Analysis. Neuropathology and Applied Neurobiology, 27, 275-280. https://doi.org/10.1046/j.0305-1846.2001.00331.x

[26] Krüger, P.G. and Mørk, S. (2012) Mast Cells and Multiple Sclerosis in Females and Males. World Journal of Neuroscience, 2, 145-149. https://doi.org/10.4236/wjns.2012.23022

[27] Rozniecki, J.J., Hauser, S.L., Stein, M., Lincoln, R. and Theoharides, T.C. (1995) Elevated Mast Cell Tryptase in Cerebrospinal Fluid of Multiple Sclerosis Patients. Annals of Neurology, 37, 63-66. https://doi.org/10.1002/ana.410370112

[28] Dropp, J.J. (1979) Mast Cells in the Human Brain. Acta Anatomica, 105, 505-513. https://doi.org/10.1159/000145157

[29] Orton, S.M., Herrera, B.M., Yee, I.M., Valdar, W., Ramagopalan, S.V., Sadovnick, 
A.D. and Ebers, G.C. (2006) Sex Ratio of Multiple Sclerosis in Canada, a Longitudinal Study. The Lancet Neurology, 5, 932-936.

https://doi.org/10.1016/S1474-4422(06)70581-6

[30] Johnson, D., Seeldrayers, P.A. and Weiner, H.L. (1988) The Role of Mast Cells in Demyelination. I Myelin Proteins Are Degraded by Mast Cell Proteases and Myelin Basic Protein and P2 Can Stimulate Mast Cell Degranulation. Brain Research, 444, 195-198. https://doi.org/10.1016/0006-8993(88)90929-8

[31] Krüger, P.G. and Lagunoff, D. (1981) Mast Cell Restoration. A Study of the Rat Peritoneal Mast Cells after Depletion with Polymyxin B. International Archives of Allergy and Immunology, 65, 278-290. https://doi.org/10.1159/000232767

[32] Hammel, I., Lagunoff, D. and Krüger, P.G. (1989) Recovery of Rat Mast Cells after Secretion: A Morphometric Study. Experimental Cell Research, 184, 518-523. https://doi.org/10.1016/0014-4827(89)90349-2

[33] Krüger, P.G. (2014) Mast Cells: The Key to Multiple Sclerosis? World Journal of Neuroscience, 4, 120-124. https://doi.org/10.4236/wjns.2014.42014

[34] Galli, S.J., Borregaard, N. and Wynn, T.A. (2011) Phenotypic and Functional Plasticity of Cells of Innate Immunity: Macrophages, Mast Cells and Neutrophils. Nature Immunology, 12, 1035-1044. https://doi.org/10.1038/ni.2109

[35] Czarnetzki, B.M., Krüger, G. and Sterry, W. (1983) In Vitro Generation of Mast Cell-Like Cells from Human Peripheral Mononuclear Phagocytes. International Archives of Allergy and Immunology, 71, 161-167.

https://doi.org/10.1159/000233381

[36] Kambayashi, C., Allenspach, E.J., Chang, J.T., Zou, T., Shang, J., Reiner, S.L., Caton, A.J. and Kretzky, G.A. (2009) Inducible HMC Class II Expression by Mast Cells Supports Effector and Regulatory T Cell Activation. The Journal of Immunology, 182, 4686-4695. https://doi.org/10.4049/jimmunol.0803180

[37] Krüger, P.G. and Nyfors, A. (1984) Phagocytosis by Mast Cells in Urticaria Pigmentosa. Acta Dermato- Venereologica, 64, 373-377.

[38] Theoharides, T.C., Alysandratos, K.-D., Angelidou, A., Delivanis, D.-A., Sismanopoulos, N., Zhang, B., Asadi, S., Vasiadi, M., Weng, Z., Minati, A. and Kalogeromitros, D. (2012) Mast Cells and Inflammation. Biochimica et Biophysica Acta, 1822, 21-33. https://doi.org/10.1016/j.bbadis.2010.12.014

[39] Esposito, P., Chandler, N., Kandere K., Basu, S., Jacobson, S., Connolly, R., Tutor, D. and Theoharides, T.C. (2002) Corticotropin-Releasing Hormone and Brain Mast Cells Regulate Blood-Brain-Barrier Permeability Induced by Acute Stress. Journal of Pharmacology and Experimental Therapeutics, 303, 1061-1066. https://doi.org/10.1124/jpet.102.038497

[40] Theoharides, T.C. and Cochrane, D.E. (2004) Critical Role of Mast Cells in Inflammatory Diseases and the Effect of Acute Stress. Journal of Neuroimmunology, 146, $1-12$.

[41] Ackerman, K.D., Heyman, R., Rabin, B.S., Anderson, B.P., Houck, P.R., Frank, E. and Baum, A. (2002) Stressful Life Events Precede Exacerbations of Multiple Sclerosis. Psychosomatic Medicine, 64, 916-920.

[42] Artemiadis, A.K., Anognostouli, M.C. and Alexopoulos, E.C. (2011) Stress as a Risk Factor for Multiple Sclerosis Onset or Relapse: A Systematic Review. Neuroepidemiology, 36, 109-120. https://doi.org/10.1159/000323953

[43] Krüger, P.G., Mahata, S.K. and Helle, K.B. (2002) Catestatin (Chromogranin A344-358) Stimulates Release of Histamine from Rat Pleural and Peritoneal Mast 
Cells. Annals of the New York Academy of Sciences, 971, 349-351.

https://doi.org/10.1111/j.1749-6632.2002.tb04493.x

[44] Moran-Ramos, S., Tovar, A.R. and Torres, N. (2012) Diet: Friend or Foe of Enteroendocrine Cells: How It Interacts with Enteroendocrine Cells. Advances in Nutrition, 3, 8-20. https://doi.org/10.3945/an.111.000976 